\title{
Pengaruh Lama Simpan dan Macam Wadah Penyimpanan terhadap Pertumbuhan dan Hasil Panen Muda Jahe Merah (Zingiber officinale Var. Rubrum. Rosc.)
}

\section{The Effect of Storage Time and Type of Storage Container on Growth and Yield of Young Red Ginger (Zingiber officinale Var. Rubrum. Rosc.)}

\author{
Mayra Auliarachma Agus dan Rohlan Rogomulyo *) \\ Departemen Budidaya Pertanian, Fakultas Pertanian, Universitas Gadjah Mada \\ Jalan Flora No. 1, Bulaksumur, Sleman, Yogyakarta 55281, Indonesia. \\ *) Penulis untuk korespodensi E-mail: rohlan_rm@yahoo.com \\ Diajukan: 10 Maret 2020 /Diterima: 31 Maret 2021 /Dipublikasi: 25 Mei 2021
}

\begin{abstract}
Red ginger is one of the agricultural commodities whose demand continues to increase from year to year both at home and abroad. Red ginger is developed because it has properties as ingredients of traditional medicine, cooking herbs, and producing aromatic compounds. Although red ginger have long been cultivated, but increased yield of red ginger has not been maximal. In addition, the development of large amounts of red ginger has not been supported by use of quality seeds. For this reason, it is necessary to develop the area of red ginger cultivation in Indonesia by providing quality seeds to support the success of red ginger cultivation, so the productivity of red ginger can increase. The research was conducted in June 2017 to March 2018 in Krapyak RT 06/RW 18 Sidoarum Village, Godean District, Sleman, Yogyakarta and Plant Ecology Laboratory, Faculty of Agriculture, Gadjah Mada University, Yogyakarta. The purpose of this research are for knowing the effect storage time and type of storage container on growth and yield of red ginger. The design used was a factorial randomized complete block design with storage time as the first factor and type of storage container as the second factor with 3 blocks as replication. Storage duration consist of 3 levels, namely 0 months, 1 months and 2 months. As for the types of storage containers, there are 3 levels, namely woven bamboo, rice sacks, and hermetic plastic. The results showed that the length of storage until 2 month using kind of storage containers in the form of woven bamboo, rice sacks, and hermetic plastik produced the same growth and yield on the rhizome.
\end{abstract}

Keywords: container; physiological quality; red ginger; storage time

\section{INTISARI}

Tanaman jahe merah (Zingiber officinale var. Rubrum. Rosc.) merupakan salah satu komoditas pertanian yang permintaannya terus meningkat dari tahun ke tahun baik di dalam maupun di luar negeri. Jahe merah dikembangkan karena memiliki khasiat sebagai bahan obat tradisional, bumbu masak, dan penghasil senyawa aromatik. Meskipun tanaman jahe merah telah lama dibudidayakan, namun peningkatan produksi jahe merah belum maksimal. Oleh karena itu, selain perluasan area tanam, penggunaan benih bermutu menjadi salah satu upaya dalam menunjang keberhasilan peningkatan produksi jahe merah di Indonesia, Mutu benih sebelum ditanam harus terjaga agar tanaman jahe merah dapat tumbuh dan menghasilkan dengan baik. Dalam penelitian ini dilakukan pengujian untuk mendapatkan lama simpan dan macam wadah penyimpanan yang berpengaruh paling baik terhadap mutu benih, pertumbuhan dan hasil jahe merah. Lama penyimpanan yang diterapkan yaitu 0 bulan, 
1 bulan, dan 2 bulan, dan macam wadah yang digunakan adalah kotak anyaman bambu (besek), karung beras, dan plastik hermetik. Hasil penelitian menunjukkan bahwa perlakuan penyimpanan sampai dengan 2 bulan menggunakan ketiga macam wadah penyimpan-an berupa keranjang anyaman bambu (besek), karung beras, dan plastik hermetik menghasilkan pertumbuhan dan bobot segar rimpang jahe merah yang sama baiknya.

Kata kunci: jahe merah; lama simpan; mutu fisiologis; wadah penyimpanan

\section{PENDAHULUAN}

Jahe merah (Zingiber officinale var. Rubrum. Rosc.) merupakan tanaman yang memiliki potensi untuk meningkatkan pendapatan petani dan devisa negara. Tanaman ini merupakan salah satu komoditas pertanian yang permintaannya terus meningkat baik di dalam maupun di luar negeri. Jahe segar di Indonesia diekspor ke berbagai negara diantaranya Amerika Serikat, Hongkong, Singapura, dan Pakistan (Balfas, 2012). Produksi jahe di Indonesia mengalami peningkatan dari tahun ke tahun yaitu pada Tahun 2012 sekitar 114.537.65 ton meningkat tajam menjadi 32.888.249 ton pada Tahun 2016 (Anonim, 2017). Dalam proses peningkatan produksi jahe merah (Zingiber officinale Var. Rubrum. Rosc.) di Indonesia, usaha pengembangan area budidaya tanaman jahe merah terus diupayakan, sehingga terjadi peningkatan permintaan bibit jahe merah dari tahun ke tahun. Untuk memenuhi kebutuhan tersebut maka pengadaan bibit yang berkualitas baik merupakan bagian yang cukup penting dalam menunjang keberhasilan budidaya jahe merah. Walaupun tanaman jahe telah lama dibudidayakan dan menjadi salah satu bahan baku obat tradisonal, herba standar dan fitofarmaka, namun pengembangan jahe dalam skala luas belum didukung oleh penyediaan benih bermutu. Mutu benih meliputi: mutu fisik (kadar air, dan penyusutan bobot rimpang), mutu genetik (kebenaran varietas), mutu fisiologis (daya tumbuh/berkecambah dan vigor benih) dan teknik budidaya yang optimal (Sukarman et al., 2008). Faktor lingkungan utama yang dapat mempengaruhi produksi benih dimulai dengan riwayat lahan, iklim (cahaya, suhu, curah hujan, dan angin), tanah (kesuburan dan kelembapan), serta faktor biologis (hama, penyakit, dan gulma) (Sadjad, 1997). Faktor lain yang mempengaruhi hasil adalah varietas, ukuran dan umur benih serta rotasi tanaman (Mugnisyah dan Setiawan, 1990). Berikut merupakan syarat mutu rimpang yang digunakan sebagai benih pokok dan benih sebar (Tabel 1) dan persyaratan mutu kebun benih (rimpang) untuk kelas Benih Pokok (BP) dan Benih Sebar (BR) yang siap tanam (Tabel 2). 
Tabel 1. Persyaratan mutu kebun benih (rimpang) untuk kelas Benih Pokok (BP) dan Benih Sebar (BR)

\begin{tabular}{clc}
\hline No & \multicolumn{1}{c}{ Jenis Spesifikasi } & Persyaratan \\
\hline 1. & Kemurnian varietas (\%) & $\geq 98$ \\
2. & $\begin{array}{l}\text { Serangan hama dan penyakit (OPT) yang tidak terbawa } \\
\text { rimpang (none seed borne) (\%) }\end{array}$ & $\leq 10$ \\
3. & Serangan OPT yang terbawa rimpang (seed borne) (\%) & 0
\end{tabular}

Sumber : Badan Standarisasi Nasional, 2006

Tabel 2. Persyaratan mutu kebun benih (rimpang) untuk kelas Benih Pokok (BP) dan Benih Sebar (BR) yang siap tanam

\begin{tabular}{clccc}
\hline \multirow{2}{*}{ No } & \multicolumn{2}{c}{ Jenis Spesifikasi } & Satuan & \multicolumn{2}{c}{ Persyaratan } \\
\cline { 5 - 5 } & & & & BP \\
\hline 1. & Berat rimpang & G & $40-60$ & $40-60$ \\
& - Jahe putih besar & G & $15-30$ & $15-30$ \\
& - Jahe putih kecil & G & $15-30$ & $15-30$ \\
& - Jahe merah & $\%$ & $\geq 70$ & $\geq 70$ \\
2. & Kadar air & $\%$ & $\geq 98$ & $\geq 97$ \\
3. & Bemih murni & Buah & $\geq 2$ & $\geq 2$ \\
4. & Jumlah mata tunas & $\%$ & $>80$ & $\geq 80$ \\
5. & Daya berkecambah & $\%$ & $<2$ & $\leq 3$ \\
6. & Kotoran benih & &
\end{tabular}

Sumber : Badan Standarisasi Nasional, 2006

Djazuli dan Sukarman (2007) mengemukakan bahwa lingkungan tumbuh arkeologi, kesuburan tanah berpengaruh terhadap komponen pertumbuhan dan hasil jahe. Rimpang jahe bersifat higroskopis, rimpang akan menyerap atau melepaskan air sampai kadar airnya mencapai keseimbangan dengan kelembapan udara di sekitarnya (Sukarman et al, 2007). Sebaiknya bibit jahe disimpan pada ruangan dengan suhu $20-25^{\circ} \mathrm{C}$, kelembapan udara $70-80 \%$, memiliki ventilasi, terhindar dari cahaya matahari langsung dan percikan air hujan, serta tidak bercampur dengan pupuk, pestisida, atau bahan kimia lain. Mudjisihono et al. (2001) mengungkapkan bahwa jenis kemasan plastik efektif untuk menghambat perubahan kadar air selama penyimpanan. Plastik hermetik adalah kantong plastik yang dibuat dari bahan khusus untuk menciptakan lingkungan hermetik, atau kedap dari pengaruh air dan udara luar, sehingga cocok untuk menyimpan dan mengawetkan hasil panen biji-bijian di wilayah tropis yang panas dan lembap. Plastik hermetik digunakan karena dapat meminimalkan pengaruh lingkungan luar. Dengan begitu kondisi awal bibit tetap terjaga sampai akhir penyimpanan. Plastik hermetik memiliki kemampuan untuk menciptakan lingkungan hermetik atau kedap dari pengaruh air dan udara luar, sehingga lingkungan di dalam plastik 
hermatik terjaga. Plastik hermatik digunakan dalam penelitian untuk mengetahui apakah dengan menyimpan rimpang jahe dalam plastik hermatik dapat mempertahankan mutu bibitnya sampai akhir penyimpanan. Tujuan dari penelitian ini adalah untuk mengetahui pengaruh lama simpan dan macam wadah penyimpanan terhadap pertumbuhan dan hasil jahe merah.

\section{BAHAN DAN METODE}

Bahan penelitian yang digunakan antara lain bibit rimpang jahe merah tua berumur lebih dari 9 bulan, yang berasal dari kelompok tani di Dusun Rajek Utara RT 02/RW 24 Desa Tirtoadi, Kecamatan Mlati, Kabupaten Sleman, Yogyakarta. Rimpang jahe merah yang akan ditanam, sebelumnya disimpan terlebih dahulu di dalam ruangan yang memiliki suhu udara berkisar $29^{\circ} \mathrm{C}-29,2^{\circ} \mathrm{C}$ dengan kelembapan udara $79 \%$ $83 \%$. Jahe yang akan disimpan, sebelumnya ditimbang terlebih dahulu untuk dilakukan pengelompokkan ukuran rimpang sesuai dengan yang sudah ditentukan sebelum-nya. Setelah rimpang sudah dikelompokkan berdasarkan ukuran, kemudian masing-masing ditempatkan di tampah besar. Penyimpanan rimpang jahe merah dimulai pada bulan Juni 2017 untuk perlakuan lama simpan 2 bulan. Kemudian pada bulan Juli 2017 dilakukan pe-nyimpanan rimpang jahe merah untuk perlakuan lama simpan 1 bulan.

Penyimpanan rimpang jahe merah dapat dilakukan dengan mengambil rimpang jahe yang sudah dikelompokkan sebelumnya, untuk masukkan ke dalam wadah penyimpanan berupa keranjang anyaman bambu (besek), karung beras, dan plastik hermetik. Selanjutnya untuk lama simpan 0 bulan, rimpang jahe merah sebelumnya tetap disimpan di atas tampah sejak bulan juni 2017 tetapi tidak diberi perlakuan penyimpanan menggunakan ketiga macam wadah. Rimpang jahe merah yang diberi perlakuan lama simpan dengan macam wadah yang berbeda, cara penyimpanannya disusun sesuai dengan urutan kombinasi perlakuan yang sudah ditentukan. Kemudian pada bulan Agustus 2017, dilakukan penanaman serentak. Rimpang jahe merah ditanam dalam polybag dengan ukuran $50 \times 50 \times 50 \mathrm{~cm}$, dengan media tanam berupa tanah yang dicampur dengan pupuk kandang kambing. Percobaan dilakukan dengan 3 ulangan sehingga dibutuhkan tiga kelompok atau blok sebagai satuan percobaan.Terdapat 9 kombinasi perlakuan dengan total 27 unit percobaan. Setiap unit percobaan terdiri atas 16 tanaman sehingga secara keseluruhan terdiri dari 432 tanaman. Dari setiap unit percobaan diambil 3 kali untuk tanaman korban. Pengambilan tanaman korban dilakukan pada saat tanaman memasuki fase lambat umur 1-4 bulan setelah tanam (bst), fase cepat umur 4-6 bulan setelah tanam (bst), dan fase pemasakan umur tanaman $>6$ bulan setelah tanam (bst). Dari setiap kombinasi perlakuan diambil sample sebanyak 1 rimpang jahe merah untuk dilakukan pengamatan terhadap kadar air dan bobot kering rimpang dengan cara ditimbang menggunakan timbangan analitik. Kemudian sisa rimpang jahe merah yang ada di wadah penyimpanan berbeda dengan waktu lama simpan yang berbeda dilakukan pengujian daya berkecambah rimpang dan ditumbuhkan untuk mengetahui partumbuhan dan hasil jahe merah setelah dilakukan lama penyimpanan dengan menggunakan macam wadah yang berbeda. Variabel pertumbuhan terdiri dari tinggi tanaman yang 
diukur menggunakan penggaris, jumlah tunas, jumlah anakan, dan jumlah daun tanaman jahe merah. Sedangkan variabel hasil jahe merah terdiri dari bobot segar rimpang panen, diameter rimpang, bobot kering rimpang panen, dan indeks panen. Indeks panen dihitung dengan rumus: $\quad \mathrm{IP}=\frac{W e}{W b}$

Keterangan: IP = Indeks panen

$\mathrm{We}=$ Bobot ekonomis

$\mathrm{Wb}=$ Bobot biologis

\section{HASIL DAN PEMBAHASAN}

Bobot awal rimpang jahe merah dapat dihitung menggunakan timbangan digital. Sebelum disimpan, rimpang jahe merah perlu ditimbang dahulu untuk mengetahui bobot awal rimpang jahe merah sebelum diberi perlakuan penyimpanan. Bobot awal rimpang dinyatakan dalam satuan gram $(\mathrm{g})$.

Tabel 3. Bobot Awal Rimpang (g) sebelum Penyimpanan

Bobot awal rimpang (g)

\begin{tabular}{ccccc}
\hline & \multicolumn{3}{c}{ Bobot awal rimpang (g) } \\
\cline { 2 - 4 } Perlakuan & W1 (besek) & W2 & W3 & Rerata \\
& & (karung beras) & (plastik hermetik) & \\
\hline L1 (0 bulan) & 524,29 & 524,74 & 526,15 & 525,06 a \\
L2 (1 bulan) & 525,00 & 524,23 & 524,50 & 524,58 a \\
L3 (2 bulan) & 525,30 & 521,87 & 526,00 & 524,39 a \\
\hline Rerata & $524,86 p$ & $523,61 p$ & $525,55 p$ & $(-)$ \\
\hline CV & & & & $0,40 \%$ \\
\hline
\end{tabular}

Tabel 3 menunjukkan bahwa tidak terdapat

rimpang dan erat hubungannya dengan interaksi antara perlakuan lama simpan dengan kandungan pati, serat dan lilin pada permukaan macam wadah penyimpan-an pada bobot awal kulit benih/rimpang (Sukarman et al., 2005). rimpang jahe merah. Selain itu tidak ada pengaruh nyata baik dari perlakuan lama simpan maupun macam wadah penyimpanan. Hal ini membuktikan bahwa rimpang jahe merah yang disiapkan untuk penelitian homogen.

Berkurangnya kadar air dalam benih berdampak terhadap berkurangnya bobot Rimpang jahe merah yang sudah diberi perlakuan lama simpan dengan macam wadah penyimpanan, kemudian ditimbang bobot akhirnya menggunakan timbangan digital. Tujuannya untuk mengetahui seberapa besar berkurangnya bobot rimpang jahe merah sesudah diberi perlakuan. benih/rimpang jahe. Tingkat penurunan bobot 
Tabel 4. Pengaruh Lama simpan dan Macam wadah Penyimpanan terhadap Bobot Akhir Rimpang Jahe Merah Segar Setelah Penyimpanan (g)

\begin{tabular}{ccccc}
\hline & \multicolumn{3}{c}{ Bobot akhir rimpang (g) } & \\
\cline { 2 - 4 } Perlakuan & W1 & W2 & W3 & Rerata \\
& (besek) & (karung beras) & $\begin{array}{c}\text { (plastik } \\
\text { hermetik) }\end{array}$ & \\
\hline L1 (0 bulan) & 301,64 a & 345,05 a & 257,16 a & 301,28 \\
L2 (1 bulan) & 293,90 a & $305,02 \mathrm{ab}$ & $287,82 \mathrm{a}$ & 295,58 \\
L3 (2 bulan) & $231,52 \mathrm{a}$ & $261,24 \mathrm{~b}$ & $310,52 \mathrm{a}$ & 267,76 \\
\hline Rerata & 275,69 & 303,77 & 285,17 & $(+)$ \\
\hline CV & \multicolumn{5}{c}{} & $12,71 \%$
\end{tabular}

Tabel 4 menunjukkan bahwa terdapat interaksi antara perlakuan lama simpan dengan macam wadah penyimpanan pada bobot akhir rimpang jahe merah setelah penyimpanan. Pada perlakuan penyimpanan menggunakan karung beras, lama simpan 0 bulan menghasilkan bobot rimpang jahe merah yang berbeda nyata dengan lama simpan 2 bulan.

Perlakuan lama simpan 2 bulan menggunakan karung beras menghasilkan bobot akhir rimpang yang nyata lebih rendah. Hal ini diduga karena karung beras yang digunakan terbuat dari bahan plastik. Bahan plastik memiliki efek solarisasi yang dapat menyebabkan suhu di dalam wadah lebih tinggi daripada suhu di ruang penyimpanan. Selain itu rimpang jahe merah bersifat higroskopis maka rimpang jahe merahakan melepaskan air sampai kadar airnya mencapai keseimbangan dengan kelembapan udara disekitarnya, sehingga menyebabkan bobot akhir rimpang jahe merah menurun karena kadar air yang terkandung dalam rimpang jahe berkurang. Tingkat penurunan bobot rimpang jahe merah erat kaitannya dengan kandungan pati, serat, dan lilin pada permukaan kulit rimpang (Sukarman et al., 2005).

Kadar air rimpang dihitung berdasarkan hasil berat basah dan berat kering. Berat kering dapat diperoleh dengan cara mengambil sample sebanyak 3 gram kemudian dikeringkan dengan oven pada suhu $70^{\circ} \mathrm{C}$, sampai kering konstan ( $\left.\pm 72 \mathrm{jam}\right)$. Setelah disimpan kadar air benih menurun, akibatnya kandungan air dalam benih berkurang, karena terjadinya proses penguapan air dari dalam benih ke permukaan benih dan dari permukaan benih ke lingkungan mikro di sekitarnya selama penyimpanan. Berkurangnya kadar air dalam benih berdampak terhadap berkurangnya bobot benih/rimpang jahe. 
Tabel 5. Kadar Air (\%) Rimpang Jahe Merah Setelah Perlakuan Lama Simpan dan Macam Wadah Penyimpanan Sebelum Ditanam

\begin{tabular}{ccccc}
\hline & \multicolumn{3}{c}{ Kadar air rimpang (\%) } & \\
\cline { 2 - 4 } Perlakuan & W1 (besek) & $\begin{array}{c}\text { W2 (karung } \\
\text { beras) }\end{array}$ & $\begin{array}{c}\text { W3 } \\
\text { (plastik } \\
\text { hermetik) }\end{array}$ & Rerata \\
\hline L1 (0 bulan) & $72 \mathrm{a}$ & $72 \mathrm{a}$ & $65 \mathrm{a}$ & 65 \\
L2 (1 bulan) & $71 \mathrm{a}$ & $68 \mathrm{a}$ & $77 \mathrm{a}$ & 77 \\
L3 (2 bulan) & $65 \mathrm{a}$ & $48 \mathrm{~b}$ & $81 \mathrm{a}$ & 81 \\
\hline Rerata & 65 & 63 & 74 & $(+)$ \\
\hline CV & & & & $13,36 \%$ \\
\hline
\end{tabular}

Tabel 6. Pengaruh Lama simpan dan Macam Wadah Penyimpanan terhadap Daya Berkecambah (\%) Rimpang Jahe Merah

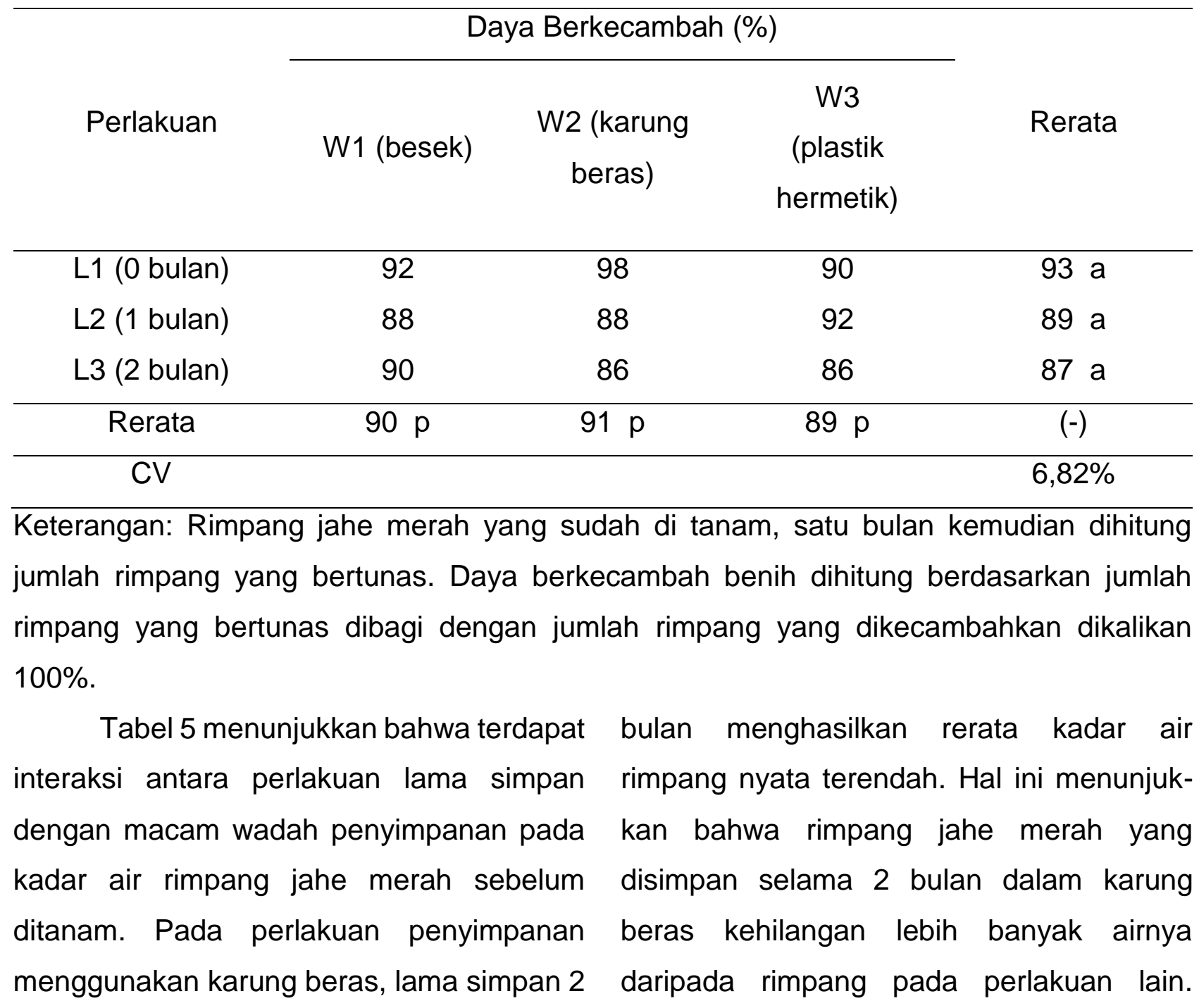


Karung beras yang digunakan untuk yang disimpan sampai dengan 2 bulan menyimpan rimpang jahe merah dalam dalam macam wadah yang berbeda penelitian ini terbuat dari bahan plastik yang menghasilkan daya berkecambah yang mempunyai efek solarisasi, hal ini sama.

menyebabkan suhu di dalam karung

Tabel 7 menunjukkan tidak terdapat menjadi lebih tinggi daripada suhu ruang penyimpanan, akibatnya kadar air pada rimpang jahe merah menjadi bekurang.

Tabel 6 menunjukkan bahwa tidak terdapat interaksi antara perlakuan lama simpan dengan macam wadah penyimpanan pada daya berkecambah rimpang jahe merah. Selain itu tidak ada pengaruh nyata baik perlakuan lama simpan maupun macam wadah penyimpanan. $\mathrm{Hal}$ ini interaksi antara perlakuan lama simpan dan macam wadah pada tinggi tanaman jahe merah 4 bst. Baik lama simpan maupun macam wadah penyimpanan tidak berpengaruh nyata terhadap tinggi tanaman jahe merah. Hal ini menunjukkan bahwa rimpang jahe merah yang disimpan sampai dengan 2 bulan dalam macam wadah penyimpanan yang berbeda menghasilkan pertumbuhan yang sama. menunjukkan bahwa rimpang jahe merah

Tabel 7. Pengaruh Lama simpan dan Macam Wadah Penyimpanan terhadap Tinggi Tanaman Jahe Merah (cm) pada 4 BST

\begin{tabular}{|c|c|c|c|c|}
\hline \multirow[b]{2}{*}{ Perlakuan } & \multicolumn{3}{|c|}{ Tinggi tanaman 4 BST $(\mathrm{cm})$} & \multirow[b]{2}{*}{ Rerata } \\
\hline & $\begin{array}{c}\text { W1 } \\
\text { (besek) }\end{array}$ & $\begin{array}{c}\text { W2 } \\
\text { (karung beras) }\end{array}$ & $\begin{array}{c}\text { W3 } \\
\text { (plastik } \\
\text { hermetik) }\end{array}$ & \\
\hline L1 (0 bulan) & 38,10 & 44,03 & 40,98 & $41,04 \mathrm{a}$ \\
\hline L2 (1 bulan) & 31,35 & 39,33 & 41,57 & 37,42 a \\
\hline L3 (2 bulan) & 32,28 & 30,08 & 36,25 & 32,87 a \\
\hline Rerata & $33,91 p$ & $37,81 p$ & $39,60 p$ & $(-)$ \\
\hline $\mathrm{CV}$ & & & & $19,96 \%$ \\
\hline
\end{tabular}


Tabel 8. Pengaruh Lama simpan dan Macam Wadah Penyimpanan terhadap Tinggi Tanaman Jahe Merah pada 6 BST $(\mathrm{cm})$

\begin{tabular}{ccccc}
\hline & \multicolumn{3}{c}{ Tingi tanaman 6 BST (cm) } & \\
\cline { 2 - 4 } Perlakuan & W1 & W2 & Rerata \\
& (besek) & (karung beras) & $\begin{array}{c}\text { W } \\
\text { (plastik } \\
\text { hermetik) }\end{array}$ & \\
\hline L1 (0 bulan) & 54,42 & 56,30 & 57,90 & $56,21 \mathrm{a}$ \\
L2 (1 bulan) & 59,38 & 62,25 & 49,78 & $57,14 \mathrm{a}$ \\
L3 (2 bulan) & 45,65 & 67,68 & 49,87 & $54,40 \mathrm{a}$ \\
\hline Rerata & $53,15 \mathrm{p}$ & $62,08 \mathrm{p}$ & $52,52 \mathrm{p}$ & $(-)$ \\
\hline CV & & & & $10,11 \%$ \\
\hline
\end{tabular}

Tabel 8 menunjukkan tidak terdapat interaksi antara perlakuan lama simpan dan macam wadah pada tinggi tanaman jahe merah 6 bst. Selain itu tidak ada pengaruh nyata baik lama simpan maupun macam wadah penyimpanan terhadap tinggi tanaman jahe merah. Hal ini menunjukkan bahwa rimpang jahe merah yang disimpan sampai dengan 2 bulan dalam tiga macam wadah penyimpanan yang berbeda menghasilkan pertumbuhan yang sama.

Tabel 9 menunjukkan tidak terdapat interaksi antara perlakuan lama simpan dan macam wadah pada jumlah tunas tanaman jahe merah 4 bst. Ada pengaruh nyata perlakuan lama simpan 0 bulan, 1 bulan, dan 2 bulan. Pada perlakuan lama simpan 0 bulan berbeda nyata dengan perlakuan lama simpan 1 bulan dan 2 bulan, hal ini menunjukkan bahwa perlakuan 0 bulan menghasilkan rerata jumlah tunas tertinggi. Jika dilihat pada tabel mutu fisik (Tabel 7.) mutu fisik rimpang berkecambah pada tanaman jahe merah yang diberi perlakuan lama simpan 0 bulan hasilnya tidak berbeda nyata dengan perlakuan lama simpan 1 bulan. Tetapi jika dilihat pada tabel daya berkecambah (Tabel 10.) pada perlakuan lama simpan 0 bulan menghasilkan rerata daya berkecambah paling tinggi, hal ini yang menyebabkan jumlah tunas pada tanaman jahe merah yang diberi perlakuan lama simpan 0 bulan memiliki jumlah tunas lebih banyak. 
Tabel 9. Pengaruh Lama simpan dan Macam Wadah Penyimpanan terhadap Jumlah Tunas Tanaman Jahe Merah pada 4 BST

\begin{tabular}{ccccc}
\hline & \multicolumn{3}{c}{ Jumlah tunas tanaman 4 BST } & \\
\cline { 2 - 4 } Perlakuan & W1 & W2 & Rerata \\
& (besek) & (karung beras) & $\begin{array}{c}\text { (plastik } \\
\text { hermetik) }\end{array}$ & \\
\hline L1 (0 bulan) & 1,07 & 1,03 & 1,23 & $1,11 \mathrm{a}$ \\
L2 (1 bulan) & 0,89 & 0,96 & 0,95 & $0,93 \mathrm{~b}$ \\
L3 (2 bulan) & 0,89 & 0,95 & 1,00 & $0,95 \mathrm{~b}$ \\
\hline Rerata & $0,95 \mathrm{p}$ & $0,98 \mathrm{p}$ & $1,06 \mathrm{p}$ & $(-)$ \\
\hline CV & & & & $12,19 \%$
\end{tabular}

Keterangan: Jumlah tunas tanaman jahe merah dihitung sebulan sekali dimulai 1 bulan setelah tanam hingga panen. Jumlah tunas dapat diketahui dengan cara menghitung semua tunas yang tidak berdaun

Tabel 10. Pengaruh Lama simpan dan Macam Wadah Penyimpanan terhadap Jumlah Tunas Tanaman Jahe Merah pada 6 BST

Jumlah tunas tanaman 6 BST

\begin{tabular}{ccccc}
\hline & \multicolumn{3}{c}{ Jumlah tunas tanaman 6 BST } & \\
\cline { 2 - 4 } Perlakuan & W1 (besek) & $\begin{array}{c}\text { W2 (karung } \\
\text { beras) }\end{array}$ & $\begin{array}{c}\text { W3 (plastik } \\
\text { hermetik) }\end{array}$ & Rerata \\
\hline L1 (0 bulan) & 1,50 & 1,00 & 2,17 & $1,56 \mathrm{a}$ \\
L2 (1 bulan) & 2,67 & 2,67 & 1,50 & $2,28 \mathrm{a}$ \\
L3 (2 bulan) & 2,00 & 1,33 & 1,00 & $1,44 \mathrm{a}$ \\
\hline Rerata & $2,06 \mathrm{p}$ & $1,67 \mathrm{p}$ & $1,56 \mathrm{p}$ & $(-)$ \\
\hline CV & & & & $16,56 \%$ \\
\hline
\end{tabular}

Tabel 10 menunjukkan tidak terdapat interaksi antara perlakuan lama simpan dan macam wadah pada jumlah tunas tanaman jahe merah pada 6 bst. Tidak ada pengaruh nyata terhadap jumlah tunas pada 6 bst, baik dari perlakuan lama simpan maupun macam wadah penyimpanan. Hal ini menunjukkan bahwa rimpang jahe merah yang disimpan sampai dengan 2 bulan dalam tiga macam wadah berbeda menghasilkan pertumbuhan tunas yang sama. 
Tabel 11. Pengaruh Lama simpan dan Macam Wadah Penyimpanan terhadap Jumlah Anakan Tanaman Jahe Merah pada 4 BST

\begin{tabular}{|c|c|c|c|c|}
\hline \multirow[b]{2}{*}{ Perlakuan } & \multicolumn{3}{|c|}{ Jumlah anakan tanaman 4 BST } & \multirow[b]{2}{*}{ Rerata } \\
\hline & $\begin{array}{c}\text { W1 } \\
\text { (besek) }\end{array}$ & $\begin{array}{c}\text { W2 } \\
\text { (karung beras) }\end{array}$ & $\begin{array}{c}\text { W3 } \\
\text { (plastik } \\
\text { hermetik) }\end{array}$ & \\
\hline L1 (0 bulan) & 2,50 & 3,33 & 2,33 & $2,72 a$ \\
\hline L2 (1 bulan) & 1,67 & 3,33 & 3,50 & $2,83 a$ \\
\hline L3 (2 bulan) & 1,83 & 1,83 & 2,50 & $2,05 \mathrm{a}$ \\
\hline Rerata & $2,00 p$ & $2,83 p$ & $2,78 p$ & $(-)$ \\
\hline CV & & & & $11,74 \%$ \\
\hline
\end{tabular}

Tabel 12. Pengaruh Lama simpan dan Macam Wadah Penyimpanan terhadap Jumlah Anakan Tanaman Jahe Merah pada 6 BST

\begin{tabular}{ccccc}
\hline & \multicolumn{3}{c}{ Jumlah anakan tanaman 6 BST } & \\
\cline { 2 - 4 } Perlakuan & W1 & W2 & $\begin{array}{c}\text { W3 } \\
\text { (plastik } \\
\text { (besek) }\end{array}$ & Rerata \\
& & 12,00 & 15,50 & $12,78 \mathrm{a}$ \\
\hline L1 (0 bulan) & 10,83 & 13,67 & 10,00 & $12,89 \mathrm{a}$ \\
L2 (1 bulan) & 15,00 & 13,50 & 9,00 & $10,67 \mathrm{a}$ \\
L3 (2 bulan) & 9,50 & $13,06 \mathrm{p}$ & $11,50 \mathrm{p}$ & $(-)$ \\
\hline Rerata & $11,78 \mathrm{p}$ & & & $16,01 \%$ \\
\hline CV & & & &
\end{tabular}

Tabel 11 menunjukkan tidak terdapat interaksi antara perlakuan lama simpan dan macam wadah terhadap jumlah anakan tanaman jahe merah pada 4 bst. Selain itu tidak ada pengaruh nyata baik lama simpan maupun macam wadah penyimpanan terhadap jumlah anakan. Hal ini menunjukkan bahwa rimpang jahe merah yang disimpan sampai dengan 2 bulan dalam tiga macam wadah penyimpanan berbeda menghasilkan pertumbuhan anakan tanaman yang sama. 
Tabel 12 menunjukkan tidak terdapat interaksi antara perlakuan lama simpan dan macam wadah pada jumlah anakan tanaman jahe merah pada 6 bst. Tidak ada pengaruh nyata baik lama simpan maupun macam wadah penyimpanan terhadap jumlah anakan pada 6 bst. Hal ini menunjukkan bahwa rimpang jahe merah yang disimpan sampai dengan 2 bulan dengan ketiga macam wadah penyimpanan berbeda menghasilkan pertumbuhan anakan tanaman yang sama.
Tabel 13 menunjukkan tidak terdapat interaksi antara perlakuan lama simpan dan macam wadah pada jumlah daun tanaman jahe merah pada 4 bst. Tidak ada pengaruh nyata baik lama simpan maupun macam wadah penyimpanan. Hal ini menunjukkan bahwa rimpang jahe merah yang disimpan sampai dengan 2 bulan dalam tiga macam wadah penyimpanan berbeda menghasilkan pertumbuhan daun yang sama.

Tabel 13. Pengaruh Lama simpan dan Macam Wadah Penyimpanan terhadap Jumlah Daun Tanaman Jahe Merah pada 4 BST

\begin{tabular}{ccccc}
\hline & \multicolumn{3}{c}{ Jumlah daun tanaman 4 BST } & \\
\cline { 2 - 4 } Perlakuan & W1 & W2 & W3 & Rerata \\
& (besek) & (karung beras) & $\begin{array}{c}\text { (plastik } \\
\text { hermetik) }\end{array}$ & \\
\hline L1 (0 bulan) & 9,33 & 10,83 & 12,67 & 10,94 a \\
L2 (1 bulan) & 9,00 & 10,50 & 10,00 & 9,83 a \\
L3 (2 bulan) & 7,50 & 9,00 & 10,33 & $8,94 \quad \mathrm{a}$ \\
\hline Rerata & $8,61 \mathrm{p}$ & $10,11 \mathrm{p}$ & $1,00 \mathrm{p}$ & $(-)$ \\
\hline CV & & & & $15,92 \%$
\end{tabular}

Keterangan: Jumlah daun tanaman jahe merah dihitung sebulan sekali dimulai umur 1 bulan setelah tanam sampai panen. Jumlah daun dapat diketahui dengan cara menghitung daun dimulai dari titik tumbuh sampai ke arah dasar batang.

Tabel 14 menunjukkan tidak terdapat interaksi antara perlakuan lama simpan dan macam wadah pada jumlah daun tanaman jahe merah pada 6 bst. Lama simpan maupun macam wadah penyimpanan tidak berpengaruh nyata terhadap jumlah daun.
Hal ini menunjukkan bahwa rimpang jahe merah yang disimpan sampai dengan 2 bulan dalam tiga macam wadah penyimpanan berbeda menghasilkan pertumbuhan daun yang sama. 
Tabel 14. Pengaruh Lama simpan dan Macam Wadah Penyimpanan terhadap Jumlah Daun Tanaman Jahe Merah pada 6 BST

\begin{tabular}{ccccc}
\hline & \multicolumn{3}{c}{ Jumlah daun tanaman 6 BST } & \\
\cline { 2 - 4 } Perlakuan & W1 & W2 & W3 & Rerata \\
& (besek) & (karung beras) & $\begin{array}{c}\text { (plastik } \\
\text { hermetik) }\end{array}$ & \\
\hline L1 (0 bulan) & 19,83 & 19,67 & 21,67 & $20,39 \mathrm{a}$ \\
L2 (1 bulan) & 22,33 & 23,00 & 18,50 & $21,28 \mathrm{a}$ \\
L3 (2 bulan) & 17,67 & 21,17 & 19,83 & $19,56 \mathrm{a}$ \\
\hline Rerata & $19,94 \mathrm{p}$ & $21,28 \mathrm{p}$ & $20,00 \mathrm{p}$ & $(-)$ \\
\hline CV & & & & $16,35 \%$ \\
\hline
\end{tabular}

Tabel 15. Pengaruh Lama simpan dan Macam Wadah Penyimpanan terhadap Bobot Segar Rimpang Panen (g)

Bobot segar rimpang panen $(\mathrm{g})$

\begin{tabular}{cccc}
\cline { 2 - 3 } Perlakuan & W1 & W2 & W3 \\
(besek) & (karung beras) & $\begin{array}{c}\text { (plastik } \\
\text { hermetik) }\end{array}$ & Rerata
\end{tabular}

\begin{tabular}{ccccc}
\hline L1 (0 bulan) & 128,72 & 117,69 & 171,74 & $139,38 \mathrm{a}$ \\
L2 (1 bulan) & 150,41 & 137,01 & 117,78 & $135,07 \mathrm{a}$ \\
L3 (2 bulan) & 116,25 & 129,10 & 141,82 & $129,06 \mathrm{a}$ \\
\hline Rerata & $131,79 \mathrm{p}$ & $127,93 \mathrm{p}$ & $143,78 \mathrm{p}$ & $(-)$ \\
\hline CV & & & & $14,78 \%$
\end{tabular}

Keterangan: Rimpang jahe merah yang sudah dipanen dibersihkan menggunakan air untuk menghilangkan tanah yang menempel pada rimpang. Kemudian rimpang jahe dikeringanginkan untuk menghilangkan sisa-sisa air di permukaan rimpang. Setelah itu, rimpang jahe merah ditimbang menggunakan timbangan digital.

Tabel 15 menunjukkan tidak terdapat maupun macam wadah penyimpanan tidak interaksi antara perlakuan lama simpan dan berpengaruh nyata terhadap bobot segar macam wadah terhadap hasil rimpang rimpang panen. Hal ini menunjukkan bahwa panen jahe merah. Baik lama simpan rimpang jahe merah yang disimpan sampai 
dengan 2 bulan dengan ketiga macam wadah penyimpanan berbeda menghasilkan rimpang panen yang sama.

Tabel 16 menunjukkan tidak terdapat interaksi antara perlakuan lama simpan dan macam wadah pada diameter rimpang panen jahe merah. Tidak ada pengaruh nyata baik lama simpan maupun macam wadah penyimpanan terhadap diameter rimpang. Hal ini menunjukkan bahwa rimpang jahe merah yang disimpan sampai dengan 2 bulan dalam tiga macam wadah penyimpanan yang berbeda menghasilkan perkembangan rimpang yang sama.

Tabel 16. Pengaruh Lama simpan dan Macam Wadah Penyimpanan terhadap Diameter Rimpang Panen (mm)

\begin{tabular}{ccccc}
\hline & \multicolumn{3}{c}{ Diameter rimpang panen $(\mathrm{mm})$} & \\
\cline { 2 - 4 } Perlakuan & W1 & W2 & R3 \\
& (besek) & (karung beras) & $\begin{array}{c}\text { (plastik } \\
\text { hermetik) }\end{array}$ & \\
\hline L1 (0 bulan) & 21,31 & 21,55 & 22,53 & 21,80 a \\
L2 (1 bulan) & 22,00 & 26,55 & 22,51 & 23,69 a \\
L3 (2 bulan) & 22,75 & 22,36 & 26,38 & 23,83 a \\
\hline Rerata & $22,02 \mathrm{p}$ & $23,49 \mathrm{p}$ & $23,81 \mathrm{p}$ & $(-)$ \\
\hline CV & & & & $11,26 \%$
\end{tabular}

Keterangan: Rimpang jahe merah yang sudah bersih, selanjutnya dilakukan pengukuran lebar atau diameter rimpang menggunakan alat berupa jangka sorong.

Tabel 17 menunjukkan tidak terdapat interaksi antara perlakuan lama simpan dan macam wadah pada bobot kering rimpang panen jahe merah. Lama simpan maupun macam wadah penyimpanan tidak berpengaruh nyata terhadap bobot kering rimpang. Hal ini menunjukkan bahwa rimpang jahe merah yang disimpan sampai dengan 2 bulan dalam tiga macam wadah penyimpanan yang berbeda menghasilkan bobot kering rimpang yang sama.
Tabel 18 menunjukkan tidak terdapat interaksi antara perlakuan lama simpan dan macam wadah pada indeks panen jahe merah. Tidak ada pengaruh nyata baik lama simpan maupun macam wadah penyimpanan. Hal ini menunjukkan bahwa rimpang jahe merah yang disimpan sampai dengan 2 bulan dalam tiga macam wadah penyimpanan yang berbeda menghasilkan indeks yang lebih kurang sama. Indeks panen yang dihasilkan bernilai 0,44-0,56 
yang berarti tanaman jahe merah dalam penelitian ini menghasilkan rimpang lebih kurang separuh dari bobot totalnya.

Tabel 17. Pengaruh Lama simpan dan Macam Wadah Penyimpanan terhadap Bobot Kering Rimpang Panen (g)

Bobot kering rimpang panen (g)

\begin{tabular}{ccccc}
\cline { 2 - 4 } Perlakuan & $\begin{array}{c}\text { W1 } \\
\text { (besek) }\end{array}$ & $\begin{array}{c}\text { W2 } \\
\text { (karung beras) }\end{array}$ & $\begin{array}{c}\text { W3 } \\
\text { (plastik } \\
\text { hermetik) }\end{array}$ & Rerata \\
\hline L1 (0 bulan) & 8,05 & 6,28 & 11,12 & $8,48 \mathrm{a}$ \\
L2 (1 bulan) & 10,19 & 6,77 & 6,28 & $7,75 \mathrm{a}$ \\
L3 (2 bulan) & 6,13 & 7,58 & 12,08 & $8,60 \mathrm{a}$ \\
\hline Rerata & $8,12 \mathrm{p}$ & $6,88 \mathrm{p}$ & $9,83 \mathrm{p}$ & $(-)$ \\
\hline CV & & & & $16,01 \%$
\end{tabular}

Keterangan: Rimpang jahe merah yang sudah dikeringanginkan dan ditimbang, kemudian dikeringkan dengan cara dioven. Rimpang jahe merah yang sudah kering kemudian ditimbang menggunakan timbangan digital untuk mengetahui bobot keringnya.

Tabel 18. Pengaruh Lama simpan dan Macam Wadah Penyimpanan terhadap Indeks Panen Jahe Merah

\begin{tabular}{ccccc}
\hline & \multicolumn{3}{c}{ Indeks panen } & \\
\cline { 2 - 4 } Perlakuan & $\begin{array}{c}\text { W1 } \\
\text { (besek) }\end{array}$ & $\begin{array}{c}\text { W2 } \\
\text { (karung beras) }\end{array}$ & $\begin{array}{c}\text { W3 } \\
\text { (plastik } \\
\text { hermetik) }\end{array}$ & \\
\hline L1 (0 bulan) & 0,48 & 0,39 & 0,56 & $0,48 \mathrm{a}$ \\
L2 (1 bulan) & 0,42 & 0,52 & 0,55 & $0,50 \mathrm{a}$ \\
L3 (2 bulan) & 0,44 & 0,41 & 0,56 & $0,47 \mathrm{a}$ \\
\hline Rerata & $0,45 \mathrm{a}$ & $0,44 \mathrm{a}$ & $0,56 \mathrm{a}$ & $(-)$ \\
\hline CV & & & & $18,74 \%$ \\
\hline
\end{tabular}




\section{KESIMPULAN}

1. Penyimpanan rimpang jahe merah sampai dengan 2 bulan menggunakan kotak anyaman bambu (besek), karung atau kantong plastik hermetik menghasilkan pertumbuhan tanaman yang tidak berbeda nyata.

2. Rimpang jahe merah yang disimpan sampai dengan 2 bulan menggunakan kotak anyaman bambu (besek), karung beras, atau kantong plastik hermetik menghasilkan bobot segar rimpang jahe merah yang tidak berbeda nyata

\section{DAFTAR PUSTAKA}

Anonim. 2017. Statistik Produksi Jahe Indonesia 2012-2016. Jakarta.

Badan Standarisasi Nasional. 2006. Standar Nasional Indonesia Nomor 01-71532006 tentang Benih Jahe (Zingiber officinale L.) Kelas Benih Pokok (BP) dan Benih Sebar (BR). Badan Standarisasi Nasional. Jakarta.

Balfas, Rodiah. 2012. Status lalat rimpang pada tanaman jahe dan strategi penanggulangannya. Jurnal Litbang Pertanian. 21(1).

Djazuli M. dan Sukarman. 2007. The effect of growth environment on growth and productivity of ginger. Prosiding Seminar Nasional XIII Persada 8-9 Agustus, 2007. Fakultas Kedokteran Hewan IPB. Bogor. pp.96-99.
Mudjisihono, R., D. Hindiarto Z., Noor. 2001. Pengaruh kemasan plastik terhadap mutu sawut kering selama penyimpanan. Jurnal Penelitian Pertanian. 20(1):55-65

Mugnisyah, W.Q. dan A. Setiawan. 1990. Pengantar Produksi Benih. Fakultas Pertanian. IPB.

Sadjad. S. 1997. Membangun Industri Benih dalam Era Agribisnis Indonesia. PT. Gramedia, Jakarta.

Sukarman, D. Rusmin dan Melati. 2008. Pengaruh lokasi produksi dan lama penyimpanan terhadap mutu benih jahe (Zingiber officinale L). Jurnal Littri. 14:119-124. 